\title{
Technology entrepreneurship research opportunities: insights from across Europe
}

\author{
Simon Mosey $^{1} \cdot$ Maribel Guerrero $^{2} \cdot$ Andrew Greenman ${ }^{1}$
}

Published online: 9 January 2016

(C) The Author(s) 2016. This article is published with open access at Springerlink.com

\begin{abstract}
Over the last two decades, the phenomenon of technology entrepreneurship has attracted the interest of researchers and policy makers due to its significant impact upon economic progress. Several authors define technology entrepreneurship as the interface of two well-established, but related fields-entrepreneurship and technological innovation. In this vein, technological opportunities can be recognized and exploited by individuals through new venture creation yet equally can be pursued by individuals or groups within existing public or private organizations. This special section provides a more fine grained understanding of technology entrepreneurship by considering interactions across these individual and organizational levels. We present three studies, empirically grounded within the specific and distinct policy contexts of Spain, Italy and the UK, that reveal new insights on the determinants of technology entrepreneurship. In this introductory paper, we consider the themes and contributions of these papers and provide an agenda for further research outlining a greater use of multi-level approaches to further our understanding of technology entrepreneurship.
\end{abstract}

Keywords Technology entrepreneurship - Entrepreneurial orientation · Corporate venturing $\cdot$ Governmental venture capital

JEL Classification $\mathrm{L} 26 \cdot \mathrm{M} 13 \cdot \mathrm{O} 31 \cdot \mathrm{O} 32$

Simon Mosey

simon.mosey@nottingham.ac.uk

Maribel Guerrero

maribel.guerrero@deusto.es

Andrew Greenman

andrew.greenman@nottingham.ac.uk

1 Haydn Green Institute for Innovation and Entrepreneurship, Nottingham University Business School, University of Nottingham, Nottingham, UK

2 Department of Business, Deusto Business School, University of Deusto, Mundaiz, 50, 20012 Donostia-San Sebastian, Spain 


\section{Introduction}

In recent years, the phenomenon of technology entrepreneurship has attracted the interest of researchers and policy makers that recognized its positive effect on economic development. Drawing from a rich tradition of research, several authors define technology entrepreneurship as the interface of two well-established, but related fields-entrepreneurship and technological innovation (Beckman et al. 2012a, b; Shane and Venkataraman 2003). Commensurate with entrepreneurship, technology entrepreneurship is a multi-dimensional concept that involves a variety of actors and different levels of analysis (Garud and Karnøe 2003). Building from studies in technological innovation, technological opportunities can be recognized and exploited by individuals through new venture creation but equally could be pursued by individuals or groups within existing public or private organizations (Clarysse et al. 2009; Parker 2011).

This special section responds to calls for more studies exploring the interactions between different levels of analysis such as the individual entrepreneur, the research group, the technology venture and support organisations such as university incubators, accelerators or science parks (Link et al. 2015). To achieve such insights the papers in this section adopt an approach advocated by Siegel and Wright (2015) and Fini et al. (2011) to empirically consider and explore specific and unique regional policy contexts towards technology transfer. By isolating such unique configurations, such as those found in different European regions, researchers can tease out the influence of university culture, regional support mechanisms and idiosyncrasies of national, regional and local policy. Moreover, if combined with a longitudinal analysis such an approach enhances the likelihood of more fine grained theory development regarding the determinants of technology transfer performance.

Previous studies considering interactions between the individual and technology venture levels of analysis have provided key insights into how human capital affects the development and performance of technology ventures (Colombo et al. 2004; Marvel and Lumpkin 2007; Mosey and Wright 2007; Wright et al. 2007). Despite these findings, there are still many themes that remain relatively unexplored (Beckman et al. 2012a). For instance, Eesley and Roberts (2012) examined whether entrepreneurial performance of technological new ventures was due to innate talent or the accumulation of entrepreneurial experience. In contrast to prior findings, they observed that the relative importance of experience versus talent changes with the context (i.e., when the current market or technology is familiar, experience dominates and vice versa). Similarly, Guerrero and PeñaLegazkue (2013) captured the positive effect of intrapreneurial experience (a specific dimension of human capital) on the creation of corporate ventures. Following these insights, the relative influence of many existing support measures (entrepreneurship education, incubators, business plan competitions, etc.) on the generation of talent and the experience of individuals clearly needs to be explored in more detail (Guerrero and Urbano 2014; Kourilsky and Walstad 2002; Wright et al. 2004; Guerrero et al. 2015).

To explore these issues, the University provides an ideal empirical setting as the antecedents of technology entrepreneurship can be unpicked without the limitations of survival bias (Gartner and Shaver 2012). Here there is an emerging interest in the often neglected intermediary levels of analysis such as the research group or the university school or department and how they support or constrain technology entrepreneurship within the university setting. A long tradition of work emphasizing that 'star scientists' can excel at traditional publications in addition to commercialising their work has been 
extended into a consideration of whether this endows similar performance advantages within a research group (Matsumoto et al. 2010). In an analogous manner, the influence of a supportive culture towards academic entrepreneurship within a department has been shown to have significant and lasting impacts upon the subsequent performance of technology ventures created within that department (Rasmussen et al. 2013). Conversely, the presence of an unsupportive head of department can provide a fundamental constraint upon the likelihood of technology entrepreneurship within that department. Perkmann and Salter (2012) subsequently call for a greater consideration of the influence of local norms and the conflicting logics between science and entrepreneurship upon university-industry relations, an argument reinforced by Link et al.'s (2007) empirical findings of the significance of informal mechanisms of university technology transfer. Conceptually Rasmussen and Wright (2015) present a competency based model highlighting how the individual, group, department and university levels can interact to enhance technology transfer performance and call for empirical examination of such interactions in underexplored settings such as mid-sized and mid ranking regional universities.

There is also a long established tradition of examining such interactions within the literature on technological innovation. Interactions between the organizational level and the external environment, have been considered in terms of organizational process/ strategies to exploit innovations (Beckman et al. 2012b; Shane and Venkataraman 2003), the attraction of venture capital investments (Florida and Kenney 1988; Gaba and Bhattacharya 2012), appropriate commercialization strategies (Gans and Stern 2003) and business models (Doganova and Eyquem-Renault 2009), among others. However, contemporary environmental conditions represent a strategic game changer for both new and existing organizations. Severe resource constraints and unpredictable market conditions create significant challenges for growth through innovation. In this sense, it is important to understand the influence of the characteristics of industrial sectors (traditional and emerged), as well as, institutional factors (government policies, university support measures, innovation and entrepreneurship systems, etc.) on the creation and the subsequent development of new technology ventures. For instance, the recent work of Mazzucato (2013) argues for a more detailed consideration of the impact of public policy and public sector investments in technology research and early stage commercialization. Mazzucato (2013) presents compelling evidence of the typically underreported and often hidden impact of government funded research and incubator support upon the emergence and growth of world leading internet and biotechnology ventures.

This special section is the result of a call for papers to address these research challenges. We received twenty eight submissions from a range of countries that were presented during the INBAM 2014 Conference. Papers were selected and double-blind reviewed. We selected the three manuscripts to be included in this special section as they adopted interesting/novel theories, used a range of methods, considered interactions across different levels of analysis, and provided relevant contributions/implications for researchers and policy makers. In sum, this special section provides a better understanding of the determinants of technology entrepreneurship grounded in the three different and specific policy contexts of Spain, Italy and the UK. Following the introduction, this manuscript is structured as follow. Part 2 describes the themes and contributions of the three papers included in this special section. Part 3 presents a research agenda for further avenues in technology transfer research building from this approach. 


\section{Themes and contributions of papers in this special section}

\subsection{The influence of entrepreneurial orientation upon research groups' performance}

Hormiga et al's. manuscript (this issue) analyses the relationship between entrepreneurial orientation and research group performance, and identifies how knowledge sharing mediates this relationship. According to the authors, a research group is the most common way to organize research within universities (Travaille and Hendriks 2010) and although previous studies have considered the strategic relevance of those groups (Van Looy et al. 2006; Matsumoto et al. 2010), fewer studies have explored the link between their strategy and performance (Wang et al. 2006; Goodall 2009). In this vein, Hormiga et al. (this issue) integrated the literature on strategic management and entrepreneurship to explore how entrepreneurial decisions and actions-an entrepreneurial orientation-can enhance performance (Van Door et al. 2013; Wiklund and Shepherd 2003; Lumpkin and Dess 1996). The authors proposed a model to explore the positive and direct relationship between entrepreneurial orientation and research publication performance (H1), as well as, the mediating role of knowledge sharing in that relationship (H2).

Following Siegel and Wright's (2015) call for more consideration of mid-range and 'typical' regional universities, the authors took a sample of 284 researchers associated to 87 research groups enrolled at a mid-range university located in an ultra-peripheral region of Spain with a sparse history of technology transfer. A simultaneous equations approach was used to test the hypotheses proposed yet the authors do not find supporting evidence of a positive relationship between entrepreneurial orientation and research publication performance. Nevertheless, the authors find that research groups could maximize their performance by sharing knowledge and developing a more entrepreneurial strategy. Relevant practical implications emerged from this research that could help research groups of public/private organizations understand that, somewhat counterintuitively, adopting a more entrepreneurial and open approach could enhance research publication performance. As a result, the evidence also provides further support for designing local policies to enhance the productivity of academic research and provides an insight into how traditional research groups within a less supportive regional context could be incentivised to begin to engage in technology transfer (Link et al. 2007).

\subsection{Entrepreneurial sensemaking and venturing activity in the regenerative medicine sector}

Johnson and Bock's paper (this issue) explores how environmental and organizational uncertainty affects individual entrepreneurial behavior through a situational analysis of resource assembly in the regenerative medicine (RM) sector. ${ }^{1}$ According to Alvarez and Barney (2005), in a high uncertainty environment, entrepreneurs struggle to identify which resources to assemble and coordinate. In these scenarios, collaboration and knowledge exchange are invaluable for the development of capabilities required to exploit opportunities (George et al. 2008). Despite offering potentially invaluable insights for theories of entrepreneurial behavior and venture growth, the development of entrepreneurial coping

\footnotetext{
${ }^{1} \mathrm{RM}$ research, which often involves the use of stem cells, is "the process of creating living, functional tissues to repair or replace tissue or organ function lost due to age, disease, damage or congenital defects" (NIH 2006).
} 
strategies under high uncertainty has proved challenging to observe empirically. Johnson and Bock (this issue) managed to gain access to the process of resource assembly and collaborative knowledge development in a sector with extremely high levels of uncertainty due to regulatory complexity alongside extreme market turbulence.

Johnson and Bock (this issue) utilized a qualitative approach based on long-form narrative interviews with a wide range of informants (RM entrepreneurs, Academic scientists, $\mathrm{RM} /$ life science support entities, and RM companies) obtained from Edinburgh BioQuarter, the commercialization arm of research output from the College of Medicine and Veterinary Medicine at The University of Edinburgh. They deployed Weick et al's. (2005) theories of organizational sense making to explain how academic entrepreneurs addressed challenges of resource assembly and collaborative knowledge development to drive venture formation and growth. These findings emphasize the importance of research showing how entrepreneurial cognition and decision-making contribute to the venture development process, especially within loosely coupled organisations such as universities and their surrounding entrepreneurial ecosystems (Link et al. 2015). In addition, the authors highlighted a critical link between the university entrepreneurial culture and subsequent venture coping strategies, as proposed by Lockett et al. (2005). A significant policy maker contribution was the cautionary note that academic scientist role-identity conflicts taking interacting with a poor institutional entrepreneurial culture for commercialization activities will prevent the implementation of coping strategies and thereby constrain technology venture development.

\subsection{Technology entrepreneurship and public venture capital}

Minola et al.'s paper (this issue) addresses two research questions: (1) Which criteria for government venture capital (GVC) investment strategy are most suited to help governmental policymakers meet their goals? and (2) How does the adoption of such criteria practically affect the GVC selection process? To answer these questions, based on the extant literature, the authors provide a framework to support GVC managers in the selection of NTBFs. A common assumption is that many governments have established GVC programs with the idea that these programs attract high-potential, under-funded firms neglected by private VCs and thus foster the additional funding of NTBFs. However, recent policy debate and academic enquiry has questioned the effectiveness of such public interventions (Colombo et al. 2011; 2014), and proposed that the identification of the most promising firms should be more cost effective and parsimonious with regards to resources (Takalo and Tanayama 2010).

Minola et al. (this issue) advocate that a compound measure of NTBFs' growth potential is an appropriate objective function for a GVC that, in addition to the pure financial goals that are typical of independent VCs, has to pursue welfare targets such as innovation and job creation. In this context, the authors proposed a screening model that allows for the straightforward discernment of growth potential NTBFs using easily available information which they tested on a sample of 257 Italian NTBFs in the period 2010-2011. Minola et al. (this issue) estimated a model that predicts the ex-ante probability that an NTBF exhibits potential for growth. Based on the evidence, the authors provided insights to advance debate and proposed implications of a comprehensive set of policy objectives on the implementation of the investment process of a GVC, thus enhancing the understanding of GVC dynamics. The proposed framework provides a guide and supports the allocation of public funds to entrepreneurial ventures and offers practical implications for public fund managers and policymakers. This approach offers conceptual support for the empirical 
evidence presented by Mazzucato (2013) of the significant impact of state funding upon technology entrepreneurship and appears particularly relevant for those European regions with a deficit of local support mechanisms.

\section{Proposed agenda for further research on technology entrepreneurship}

Based on the emerging themes from the three papers and extant research, we identify several research opportunities to gain new insights into the determinants of technology entrepreneurship. We present these within two categories: opportunities at the nexus of the individual and organizational level and opportunities to examine the interactions between the organizational and environmental levels.

\subsection{The individual-organizational level nexus}

Perkmann and Salter (2012) eloquently characterize the individual conflict at the heart of a technology venture as a tension between scientific and entrepreneurial logics. Yet this tension does not exist in a vacuum. Bercovitz and Feldmann (2006) show how social context and professional relationships influence which logic dominates and highlight the need to understand the organizational context within which technology entrepreneurship is enabled or constrained. The papers in this special issue have highlighted empirically how the individual-organizational level nexus can be explored, yet there are numerous opportunities to examine this nexus using different theoretical approaches. For instance, Rasmussen et al (2011) adopt Hayton and Kelley's (2006) competency theory, built within corporate venturing and use this to explain how academic entrepreneurs develop competencies together with industrial partners in the creation of university spin offs. Such a competency approach could be applied to better explain the relative efficacy of different support measures for academic entrepreneurs such as incubators, accelerators and science and technology parks (Link et al. 2015).

In a similar vein, the use of institutional theory (Greenwood and Hinings. 1996) has proven illuminating in explaining the differential performance of academic entrepreneurs based within different cross disciplinary research institutes (Mosey et al. 2012). Taking an institutional theory approach could also prove insightful when expanding the locus of study beyond traditional definitions of academic entrepreneurship. For instance, new theories could be built by considering reconceptualised aspects of academic entrepreneurship, such as student and alumni entrepreneurs, hackathons and entrepreneurship garages (Siegel and Wright. 2015).

\subsection{The interaction between the organizational and environmental levels}

Fini et al.'s. study (2011) across different regions of Italy show how new insights can be gained by examining the interaction between university spin offs and the external environment across variations of university and local support mechanisms. Through examining peculiarities of university and regional policy, infrastructure and technology receptiveness they demonstrate how universities can substitute for an unsupportive regional environment and vice versa. This theme is extended by the papers in this section as they build contingency theory, highlighting that different organizational arrangements can therefore be valid for different external conditions and enhanced effectiveness can be related to fit 
amongst the pattern of relevant contextual, structural and strategic factors (Allen and O'Shea 2014). For instance, Johnson and Bock's paper (this issue) uses the peculiarities of the Scottish regional context juxtaposed with the nascent market for regenerative medicine to extend the explanatory reach of the promising theory of sensemaking (Weick et al. 2005). Such a process based approach holds great potential for opening up the 'black box' of nascent technology entrepreneurship due to the inherent dynamic and turbulent nature of the context and the multiple iterations between individual, organizational and environmental levels (Dimov 2010).

We therefore present the opportunity for researchers to seek such natural experiments as highlighted across the different Spanish, Italian and UK regions and use such settings to explore the contingencies of organizational effectiveness for the following research questions:

- How do the local strategies/programmes/policies influence the development and growth of new technology ventures (created by individuals/existing organizations) in certain industrial sectors and regions?

- How do the dynamics of innovation/entrepreneurship ecosystems influence the strategies of technology ventures?

- What are the social and economic impacts generated by technology entrepreneurship and how do they substitute or complement for local support mechanisms?

We conclude by noting that technology entrepreneurship has come of age as a discipline of study. We are no longer debating how it should be defined, and whether it is important, but should focus upon how best to investigate, analyse and share how technology entrepreneurship can be encouraged across the myriad of international regions and universities that seek to do so.

Acknowledgments Previous versions of the papers included in this special section were presented at the INBAM Conference held in Barcelona (Spain) in November 2014. We acknowledge the support of the INBAM Organizing Committee (Dr. David Urbano and Dr. Michael Willoughby). We also extend our thanks to the reviewers for their timely and constructive responses that were subsequently adopted within the presented version of those manuscripts.

Open Access This article is distributed under the terms of the Creative Commons Attribution 4.0 International License (http://creativecommons.org/licenses/by/4.0/), which permits unrestricted use, distribution, and reproduction in any medium, provided you give appropriate credit to the original author(s) and the source, provide a link to the Creative Commons license, and indicate if changes were made.

\section{References}

Allen, T. J., \& O'Shea, R. P. (2014). Building technology transfer within research universities. Cambridge, UK: Cambridge University Press.

Alvarez, S. A., \& Barney, J. B. (2005). How do entrepreneurs organize firms under uncertainty? Journal of Management, 31(5), 776-793.

Beckman, C. M., Eisenhardt, K., Kotha, S., Meyer, A., \& Rajagopalan, N. (2012a). The role of the entrepreneur in technology entrepreneurship. Strategic Entrepreneurship Journal, 6(3), 203-206.

Beckman, C. M., Eisenhardt, K., Kotha, S., Meyer, A., \& Rajagopalan, N. (2012b). Technology entrepreneurship. Strategic Entrepreneurship Journal, 6(2), 89-93.

Bercovitz, J., \& Feldmann, M. (2006). Entrepreneurial universities and technology transfer: A conceptual framework for understanding knowledge-based economic development. Journal of Technology Transfer, 31, 175-188.

Clarysse, B., Mosey, S., \& Lambrecht, I. (2009). New trends in technology management education: A view from europe. Academy of Management Learning and Education, 8(3), 427. 
Colombo, M., Cumming, D., \& Vismara, S. (2014). Governmental venture capital for innovative young firms. Journal of Technology Transfer, 12, 1-15.

Colombo, M. G., Delmastro, M., \& Grilli, L. (2004). Entrepreneurs' human capital and the start-up size of new technology-based firms. International Journal of Industrial Organization, 22(8), 1183-1211.

Colombo, M. G., Grilli, L., \& Murtinu, S. (2011). R\&D subsidies and the performance of high-tech startups. Economics Letters, 112(1), 97-99.

Dimov, D. (2010). Nascent entrepreneurs and venture emergence: opportunity configuration, human capital and early planning. Journal of Management Studies, 47(6), 1123-1153.

Doganova, L., \& Eyquem-Renault, M. (2009). What do business models do? Innovation devices in technology entrepreneurship. Research Policy, 38(10), 1559-1570.

Eesley, C. E., \& Roberts, E. B. (2012). Are you experienced or are you talented? When does innate talent versus experience explain entrepreneurial performance? Strategic Entrepreneurship Journal, 6, 207-219.

Fini, R., Grimaldi, R., Santoni, S., \& Sobrero, M. (2011). Complements or substitutes? the role of universities and local context in supporting the creation of academic spin-offs. Research Policy, 40, 1113-1127.

Florida, R., \& Kenney, M. (1988). Venture capital and high technology entrepreneurship. Journal of Business Venturing, 3(4), 301-319.

Gaba, V., \& Bhattacharya, S. (2012). Aspirations, innovation, and corporate venture capital: a behavioral perspective. Strategic Entrepreneurship Journal, 6(2), 178-199.

Gans, J. S., \& Stern, S. (2003). The product market and the market for "ideas": Commercialization strategies for technology entrepreneurs. Research Policy, 32(2), 333-350.

Gartner, W. B., \& Shaver, K. G. (2012). Nascent entrepreneurship panel studies: Progress and challenges. Small Business Economics, 39, 659-665.

Garud, R., \& Karnøe, P. (2003). Bricolage versus breakthrough: Distributed and embedded agency in technology entrepreneurship. Research Policy, 32(2), 277-300.

George, G., Kotha, R., \& Zheny, Y. (2008). Entry into insular domains: A longitudinal study of knowledge structuration and innovation in biotechnology firms. Journal of Management Studies, 45(8), $1448-1474$.

Goodall, A. (2009). Highly cited leaders and the performance of research universities. Research Policy, 38, 1079-1092.

Greenwood, R. C., \& Hinings, C. R. (1996). Understanding radical organizational change: Bringing together the old and the new institutionalism. Academy of Management Journal, 21(4), 1022-1054.

Guerrero, M., Cunningham, J. A., \& Urbano, D. (2015). Economic impact of entrepreneurial universities' activities: An exploratory study of the United Kingdom. Research Policy, 44(3), 748-764.

Guerrero, M., \& Peña-Legazkue, I. (2013). The effect of intrapreneurial experience on corporate venturing: Evidence from developed economies. International Entrepreneurship and Management Journal, 9(3), 397-416.

Guerrero, M., \& Urbano, D. (2014). Academics' start-up intentions and knowledge filters: An individual perspective of the knowledge spillover theory of entrepreneurship. Small Business Economics, 43(1), 57-74.

Hayton, J. C., \& Kelley, D. J. (2006). A competency based framework for promoting corporate entrepreneurship. Human Resource Management, 45(3), 407-427.

Kourilsky, M. L., \& Walstad, W. B. (2002). The early environment and schooling experiences of hightechnology entrepreneurs: Insights for entrepreneurship education. International Journal of Entrepreneurship Education, 1(1), 1-20.

Link, A. N., Siegel, D. S., \& Bozeman, B. (2007). An empirical analysis of the propensity of academics to engage in informal university technology transfer. Industrial and Corporate Change, 16, 641-655.

Link, A. N., Siegel, D., \& Wright, M. (2015). An editors' introduction. In A. L. Link, D. Siegel, \& M. Wright (Eds.), The Chicago Handbook of University Technology Transfer and Academic Entrepreneurship. Chicago: The University of Chicago Press.

Lockett, A., Siegel, D., Wright, M., \& Ensley, M. D. (2005). The creation of Spin-off firms at public Research institutions: Managerial and policy implications. Research Policy, 34, 981-993.

Lumpkin, G. T., \& Dess, G. G. (1996). Clarifying the entrepreneurial orientation construct and linking it to performance. Academy of Management Review, 21(1), 165-172.

Marvel, M. R., \& Lumpkin, G. T. (2007). Technology entrepreneurs' human capital and its effects on innovation radicalness. Entrepreneurship Theory and Practice, 31(6), 807-828.

Matsumoto, M., Yokota, S., Naito, K., \& Itoh, J. (2010). Development of a model to estimate the economic impacts of R\&D output of public research institutes. R\&D Management, 40, 91-100. 
Mazzucato, M. (2013). The Entrepreneurial State: Debunking private vs Public Sector Myths. London: Anthem Press.

Mosey, S., \& Wright, M. (2007). From human capital to social capital: A longitudinal study of technology based academic entrepreneurs. Entrepreneurship Theory and Practice, 31(6), 909-935.

Mosey, S., Wright, M., \& Clarysse, B. (2012). Transforming traditional University structures for the knowledge economy through multi-disciplinary institutes, Cambridge Journal of Economics, 36(3), 587-607, Special Issue 'Universities as Strategic Actors in the Knowledge of Economy'.

NIH, Regenerative Medicine Fact Sheet. (2006). http://report.nih.gov/NIHfactsheets/Pdfs/ RegenerativeMedicine(NIBIB).pdf. Accessed 04/07/13.

Parker, S. C. (2011). Intrapreneurship or entrepreneurship? Journal of Business Venturing, 26(1), 19-34.

Perkmann, M., \& Salter, A. (2012). How to create productive partnerships with Universities. MIT Sloan Management Review, 53, 79-88.

Rasmussen, E., Mosey, S., \& Wright, M. (2011). The evolution of entrepreneurial competencies: A longitudinal study of university spin-off venture emergence. Journal of Management Studies, 48(6), 1314-1345.

Rasmussen, E., Mosey, S., \& Wright, M. (2013). The influence of university departments on the evolution of entrepreneurial competencies in spin-off ventures. Research Policy, 43(1), 92-106.

Rasmussen, E., \& Wright, M. (2015). How can universities facilitate academic spin offs? An entrepreneurial competency perspective. The Journal of Technology Transfer, 40(5), 782-799.

Shane, S., \& Venkataraman, S. (2003). Guest editors' introduction to the special issue on technology entrepreneurship. Research Policy, 32(2), 181-184.

Siegel, D. S., \& Wright, M. (2015). Academic Entrepreneurship: Time for a Rethink? British Journal of Management, 26(4), 582-595.

Takalo, T., \& Tanayama, T. (2010). Adverse selection and financing of innovation: Is there a need for R\&D subsidies? The Journal of Technology Transfer, 35(1), 16-41.

Travaille, A. M., \& Hendriks, P. H. J. (2010). What keeps science spiralling? Unravelling the critical success factors of knowledge creation in university research. Higher Education, 59(4), 423-439.

Van Doorn, S., Jansen, J. J. P., Van den Bosch, F. A. J., \& Volberda, H. W. (2013). Entrepreneurial orientation and firm performance: Drawing attention to the senior team. Journal of Product Innovation Management, 30(5), 821-836.

Van Looy, B., Callaert, J., \& Debackere, K. (2006). Publication and patent behavior of academic researchers: Conflicting, reinforcing or merely co existing? Research Policy, 35, 596-608.

Wang, E. T. G., Ying, T., Jiang, J. J., \& Klein, G. (2006). Group cohesion in organizational innovation: An empirical examination of ERP implementation. Information and Software Technology, 48(4), 235-244.

Weick, K. E., Sutcliffe, K. M., \& Obstfeld, D. (2005). Organizing and the process of sensemaking. Organization Science, 16(4), 409-421.

Wiklund, J., \& Shepherd, D. (2003). Knowledge-based resources, entrepreneurial orientation, and the performance of small and medium-sized business. Strategic Management Journal, 24(13), 1307-1314.

Wright, M., Birley, S., \& Mosey, S. (2004). Entrepreneurship and university technology transfer. The Journal of Technology Transfer, 29(3-4), 235-246.

Wright, M., Hmieleski, K. M., Siegel, D. S., \& Ensley, M. D. (2007). The role of human capital in technological entrepreneurship. Entrepreneurship Theory and Practice, 31(6), 791-806. 